\title{
A New and Validated, Randomised, Controlled Placebo Water Development Trial for Medicinal Water-based Research
}

\author{
BALAZS NEMETH ${ }^{1,2}$, ADRIENN HANZEL ${ }^{1}$, KAROLY BERENYI $^{1}$, IVAN PETER ${ }^{2}$, CSILLA HETESI $^{2}$, \\ ZENO AJTAY ${ }^{2}$, AGNES SZENCZI ${ }^{1}$, ANDRAS SUMEGI ${ }^{1}$ and KATALIN SZENDI ${ }^{1}$ \\ ${ }^{1}$ Department of Public Health Medicine, Medical School, University of Pécs, Pécs, Hungary; \\ ${ }^{2}$ Harkány Spa Hospital, Harkány, Hungary
}

\begin{abstract}
Background/Aim: To develop and validate an easy-to-use and cheap method capable of producing placebo from tap water for medicinal water efficacy trials. Patients and Methods: Patients were divided into two groups, medicinal water and tap water group. A single 20-minutelong treatment was performed in bathtubs. Patients were asked four times during the bath to tell if they were treated with medicinal water, tap water, or could not decide. Patients were scored, one point was given for each correct answer. Results: A total of 174 patients were enrolled. No significant differences were found either between the average scores or the answers of the two groups. Being familiar with the Harkany medicinal water did not influence the rate of correct answers either. There was no statistically significant difference in the number of changes of opinions between the two groups. Conclusion: The used method is appropriate for producing a validated placebo from tap water.
\end{abstract}

Natural waters with high mineral content $(>1 \mathrm{~g} / \mathrm{l})$ have been used for curative purposes since the Romans $(1,2)$. Nowadays, medicinal waters are widely used in numerous countries as non-pharmacological therapies of musculoskeletal, dermatological and gynaecological diseases (3). The unique medicinal water of Harkány originates at a depth of around 70 metres and can reach $62^{\circ} \mathrm{C}$. Its mineral content is $990 \mathrm{mg} / \mathrm{L}$. For medical purposes, its most significant mineral component is carbonyl sulphide (COS), which is dissolved in the water under pressure. Depressurized carbonyl sulphide immediately starts to decompose forming $\mathrm{H}_{2} \mathrm{~S}$ gas, giving the water its signature smell. The carbonyl

This article is freely accessible online.

Correspondence to: Ágnes Szenczi, Department of Public Health Medicine, University of Pécs Medical School, Szigeti str. 12., 7624 Pécs, Hungary. Tel: +36 72536394, e-mail: agnes.szenczi@aok.pte.hu

Key Words: Medicinal water, placebo, balneotherapy, trial. sulphide concentration of the water is around $12 \mathrm{mg} / \mathrm{l}$, and has a 150 times higher absorption rate than that of other sulphur compounds (e.g., sulphates) in the water. Ninety \% of patients with musculoskeletal diseases suffer from degenerative joint and spinal disorders. Absorbed by the cartilages, sulphur compounds play an important role in regenerating the damaged tissue $(4,5)$. Although, it has recently been suggested that the measured healing effects of medicinal waters were due to their biologically active organic substances rather than the inorganic components (6-11). Table I shows the inorganic compounds of the Harkány medicinal water (5).

Usually, medicinal water is administered in individual bathtubs or pools in 20-30-minute-long sessions $(3,12)$. Plenty of studies have been performed to prove the beneficial effects of medicinal waters. As Hungary is rich in medicinal waters, the beneficial effects of these waters have been widely studied. Bender et al. (13) performed a meta-analysis and systematic review to assess the effectivity of balneotherapy in some diseases in Hungary.

Placebos have inert content, they are used as controls in clinical trials and drug research where they look identical to the drug or treatment, while the placebo effect is a complex physical and psychological response following the administration of a placebo. Placebo effect can be beneficial; patients' symptoms may improve, or they may develop side effects to the placebo treatment. The objective of testing drugs is to compare the new drug to the drug's placebo to find out whether the new drug is better than something without active medication (14). The same principal should be applied to medicinal waters as well. Each medicinal water can be considered as a complex of organic- and inorganic compounds much like a multi-component pill or tablet. As such, it should be considered similar to the active ingredient of pharmacological treatments. Therefore, before comparing balneotherapy with other types of treatments (pharmacological or non-pharmacological), it is reasonable to perform a study with placebo control proving that the medicinal water is more effective than the placebo control water. Implementing such a 
Table I. Inorganic compounds of the Harkány medicinal water.

\begin{tabular}{lc}
\hline Chemical data & $\mathrm{mg} / \mathrm{l}$ \\
\hline $\mathrm{K}^{+}$ & 15.5 \\
$\mathrm{Na}^{+}$ & 158 \\
$\mathrm{NH}^{4+}$ & 1.88 \\
$\mathrm{Ca}^{2+}$ & 50 \\
$\mathrm{Mg}^{2+}$ & 11.2 \\
$\mathrm{Fe}^{2+}$ & 0.01 \\
$\mathrm{Mn}^{2+}$ & 0 \\
$\mathrm{Li}^{+}$ & 0 \\
$\mathrm{NO}^{3-}$ & 0.4 \\
$\mathrm{NO}^{2-}$ & 0 \\
$\mathrm{Cl}^{-}$ & 105 \\
$\mathrm{Br}^{-}$ & 0.61 \\
$\mathrm{I}^{-}$ & 0.12 \\
$\mathrm{~F}^{-}$ & 1.39 \\
$\mathrm{SO}_{4}{ }^{2-}$ & 6.9 \\
$\mathrm{HCO}_{3}^{-}$ & 525 \\
$\mathrm{~S}^{-}$ & 12.4 \\
$\mathrm{H}_{2} \mathrm{SiO}_{3}$ & 55 \\
$\mathrm{CO}_{2}$ & 242 \\
$\mathrm{O}_{2}$ & Not detectable \\
\hline
\end{tabular}

study can be challenging since the production of an indistinguishable placebo water is much more difficult than that of a placebo tablet [e.g., production of a placebo for the water of the Dead Sea $(15,16)$ requires masking its buoyancy]. In the case of placebo tablets, it is not necessary to examine whether the patients could differentiate between the two similar tablets (real, placebo), while with medicinal waters randomized controlled trials (RCTs) are essential to validate the placebo since environmental factors (e.g., ventilation, location) and physical properties (e.g., volume, buoyancy, colour) influence the identification of the placebo water.

Furthermore, when an effective treatment already exists for a medical condition, that treatment cannot be disrupted for the duration of the study for ethical reasons, in this case the traditional treatment has to be administered both to the medicinal water and to the control group, which also means that only the additional effects of the medicinal water can be studied. The following cited studies administered "placebo treatment" to the control group, as generally required by clinical trials, assessing the effectivity of a treatment.

Szúcs et al. (17) claimed that "The colour of the Püspökladány thermal water hardly differs from that of tap water, therefore there was no need to use colouring agent to ensure satisfactory placebo water". However, this was not proven by any preconception study. Furthermore, the statement becomes very disputable when looking at the colour of the Püspökladány medicinal water, the hue can also be observed in commercially available photos (18). The same issue comes up again in a different study performed by
Table II. Chemical composition of the tap water.

\begin{tabular}{|c|c|}
\hline Chemical data & $\mathrm{mg} / \mathrm{l}$ \\
\hline $\mathrm{Na}^{+}$ & 16 \\
\hline $\mathrm{NH}^{4+}$ & $<0.02$ \\
\hline $\mathrm{NO}^{3-}$ & 11.1 \\
\hline $\mathrm{NO}^{2-}$ & $<0.01$ \\
\hline $\mathrm{Cl}^{-}$ & 10 \\
\hline $\mathrm{F}^{-}$ & $<0.10$ \\
\hline \multirow{3}{*}{$\begin{array}{l}\mathrm{SO}_{4}{ }^{2-} \\
\mathrm{S}^{2-}\end{array}$} & 1.1 \\
\hline & $<0.05$ \\
\hline & $\mu \mathrm{g} / 1$ \\
\hline $\mathrm{Fe}^{2+}$ & $<20$ \\
\hline $\mathrm{Mn}^{2+}$ & $<10$ \\
\hline \multirow[t]{2}{*}{$\mathrm{As}^{3+}$} & 1.1 \\
\hline & ${ }^{\circ} \mathrm{dH}$ \\
\hline Total hardness & 20.4 \\
\hline
\end{tabular}

Bálint et al. (19, 20). In another paper investigating the therapeutic effects of a medicinal water on knee osteoarthritis, the authors used "a mixture of tap water and thermal water of negligible mineral content" as a placebo preparation. Nonetheless, this statement was not supported by any measurement or pilot study either (21).

The common issue in these studies is that it has never been examined whether the patients could actually differentiate between the two waters. If they realise which treatment they receive, the patients could involuntarily alter the results, thus the clinical trial will be of lesser value since the single-blind setup criteria are conflicted. Consequently, the beneficial effects of the medicinal water cannot be distinguished from the placebo effect.

Karagülle et al. (3) performed a systematic review summarizing the available evidences on the effectiveness of balneotherapy on chronic low back pain (LBP). After screening 138 potentially relevant articles, the authors could only include 8 RCTs, which were generally low quality (mainly due to methodical errors, e.g., lack of placebo). After reviewing the evidence, Karagülle et al. concluded that the "evidence on effectiveness of balneotherapy and spa therapy as therapy options in the treatment of LBP is yet insufficient and not conclusive (3)."

Forestier and Francon performed a similar review (22) investigating the effect of balneotherapy on knee osteoarthritis. The authors came to the very same conclusion, namely that more and higher quality studies are needed to prove the effectivity of medicinal waters. 
Table III. Questionnaire for patients.

\begin{tabular}{|c|c|c|c|}
\hline Is there medicinal water or tap water in the bathtub? & & Answers & \\
\hline Before treatment & Medicinal water & Tap water & Cannot decide \\
\hline 10 minutes after the beginning of the treatment - submerged in water & Medicinal water & Tap water & Cannot decide \\
\hline Immediately after the treatment & Medicinal water & Tap water & Cannot decide \\
\hline After having a shower & Medicinal water & Tap water & Cannot decide \\
\hline
\end{tabular}

Taking these results into account, it seems to be essential to perform placebo controlled RCTs to prove the "medication-like" effects of medicinal waters. However, the lack of proper placebo substance makes these investigations impossible. To facilitate evidence-based balneology research, we aimed to develop and validate an easy-to-use and cheap method capable of producing placebo from tap water in the case of the Harkány medicinal water (This study did not aim to examine the "placebo effect".)

\section{Patients and Methods}

Trial design. This was a randomised (1:1 for two groups) tripleblind, controlled, parallel-group study conducted at the Harkány Spa Hospital; Harkány, Hungary in the ISO 9001 accredited Balneology Unit from January 2020 to March 2020.

Informed written consent to participate in the study and to publish the collected data was obtained from every patient. The study protocol was approved by the Regional Ethics Committee of University of Pécs, Pécs, Hungary (Permission No.: 7740-PTE 2019), in accordance with the Declaration of Helsinki. This trial was prospectively registered at ClinicalTrials.gov (ID: NCT04290143).

Participants, randomization and blinding. Patients from Harkány Spa Hospital, who met the inclusion and exclusion criteria, were enrolled in the study.

Inclusion criteria were willingness to participate in the study, age between 18-80 years. Patients physically unable to enter or exit the bathtub, suffering from autoimmune diseases, any type of malignity, ongoing acute inflammation, infection, acute coronary syndrome or recent surgical interventions ( 6 months before enrolment) were excluded.

The patients were randomly divided into two groups, medicinal water and tap water group. Coin flip method was used to generate the random allocation sequence. The person responsible for the randomization process was never in contact with the patients. A data sheet containing medical history and demographical data was filled in by another investigator.

Investigators who conducted the randomization, patient coordination during treatment and statistical analysis had no contact with each other. The study was performed in a triple-blind setup where participants, data collectors and data analysts were all unaware of the treatment the participant received. Although, the question of the present study was to confirm if participant blinding was successful regarding the similarity of the medicinal and the control tap water.
Intervention. The patients were randomly divided into two groups, medicinal water and tap water group. A single 20-minute-long treatment was performed in bathtubs. Special attention was payed to ask whether the participants were previously treated with Harkány medicinal water. Both Harkány medicinal water and tap water were coloured with commercially available water colouring tablets (DmDrogerie Markt GmbH+Co. KG, DM-Platz 1, Karlsruhe, Germany, LOT: L2999003). The $\mathrm{pH}$ of the tap water was measured $(\mathrm{pH}=6.41)$ (Adwa AD11, ADWA Hungary) and no differences were found compared to the $\mathrm{pH}$ of the medicinal water $(\mathrm{pH}=6.38)$, thus adjusting was not required. Chemical composition of the tap water is shown in Table II (data were provided by BARANYA-VÍZ Zrt., a water utility service provider of Baranya County). The temperature of the tap water was adjusted to the temperature of the medicinal water. Considering the medicinal water's sulphurous odour, the treatment was given in the same room.

Outcomes. During the single 20-minute-long treatment in bathtubs, patients were asked to tell if they were treated with a) medicinal water, b) tap water, or c) cannot decide. This question was asked four times: first before coming into contact with the water, only by inspection; then in the tub 10 minutes later; after that, immediately after the treatment; and finally, after having a shower with tap water (Table III).

Each time the patients answered correctly, they were scored with 1 point. Therefore, the maximum was 4 points. Differences in answers between the two groups and the number of changes of opinions were also assessed as outcomes.

Statistical analysis. Statistical analysis was performed by IBM SPSS Statistics for Windows Version 26. Shapiro-Wilk test was used to assess normality. Differences in clinical characteristic of the two group were calculated with Independent-Sample $t$-test (for age), Mann-Whitney test (for BMI) and Chi-square test (for the rest). Differences in the scores of correct answers of the two groups and the number of changes of opinions were investigated by Mann-Whitney test. Differences in answers between the two groups were examined by Chi-square test. Subgroup analysis was performed in the age groups of 44-59, 60-69, and 70-84 using Chisquare test. All $p$-values less than 0.05 were considered statistically significant.

The sample size was calculated (23) based on our pilot study with 24 patients. Power analysis $(\alpha=0.05 ; \beta=0.90)$ determined that a sample size of 72 patients in each group would be required to detect differences in the scores of correct answers between the two groups with a standard deviation (SD) of 1.073 (although in the present study the anticipated result would be a non-significant difference between the correct answers given by the two groups). Assuming a dropout rate of $20 \%$, at least 150 patients were required for the study. 


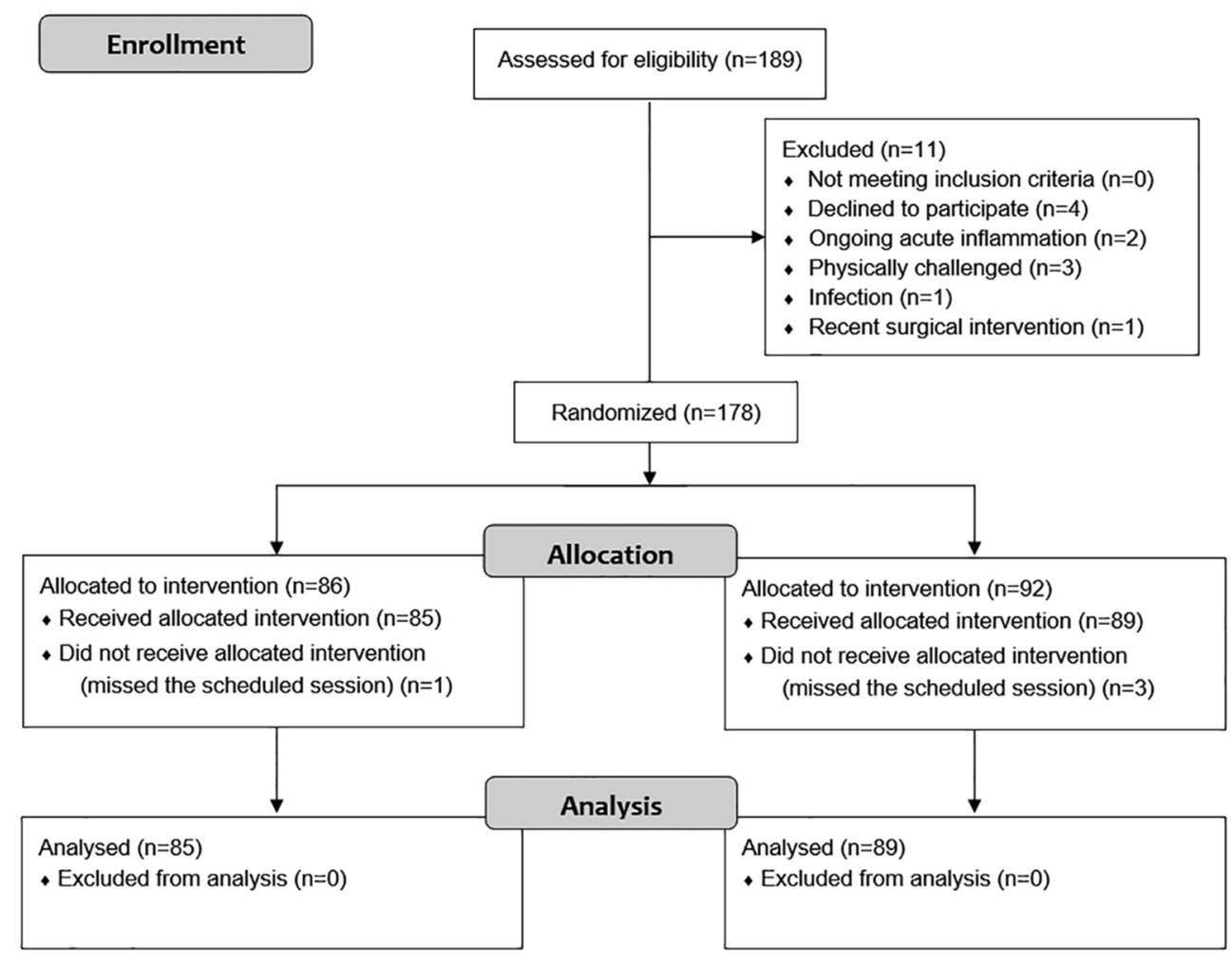

Figure 1. CONSORT flow diagram.

\section{Results}

Overall, 189 patients were enrolled in the study. Eleven patients were excluded, 178 were randomised, but four of them missed the scheduled session (Figure 1). The average age of the patients was $65.16 \pm 8.24$ years. The detailed clinical characteristics of the involved patients are presented in Table IV. No significant difference was found between the average scores of the two groups $(p=0.128)$. Scores of the two groups are shown in Table V. Regarding the differences between the answers of the two groups, significant difference was found only in the answers to the first question (before treatment, $p=0.048$ ). Otherwise, there were no significant differences between the answers of the two groups. The summary of answers is presented in Figure 2.

As there was a significant difference between the age of the two groups, a subgroup analysis was performed (patients were grouped according to age in years from 44-59, 60-69, and 70$84)$. The analysis revealed significant difference in the case of the first question (before treatment) in age group 60-69 years (27.9\% of the patients treated with tap water answered medicinal water $v s .7 .5 \%$. of the patients treated with medicinal water answered tap water). Apart from the first question (before treatment), the analysis did not reveal significant differences in
Table IV. Clinical characteristics of the involved patients.

\begin{tabular}{lccc}
\hline & $\begin{array}{c}\text { Medicinal water } \\
\mathrm{n}=85\end{array}$ & $\begin{array}{c}\text { Tap water } \\
\mathrm{n}=89\end{array}$ & $p$-Value \\
\hline Age, mean (SD) & $63.71(8.22)$ & $66.51(8.11)$ & $\mathbf{0 . 0 2 2}$ \\
BMI, median (IQR) & $28.41(5.75)$ & $28.73(5.69)$ & 0.948 \\
Male, n (\%) & $37(44)$ & $36(40)$ & 0.681 \\
Hypertension, n (\%) & $55(65)$ & $61(69)$ & 0.519 \\
Diabetes mellitus, n (\%) & $17(20)$ & $22(25)$ & 0.456 \\
Rheumatoid arthritis, n (\%) & $57(67)$ & $56(63)$ & 0.567 \\
Psoriasis, n (\%) & $12(14)$ & $21(24)$ & 0.111 \\
Previously treated with & $63(74)$ & $70(79)$ & 0.481 \\
Harkány medicinal water, n (\%) & & \\
\hline
\end{tabular}

Bold value indicates statistical significance.

the answers of the two groups. Neither did the analysis show differences in the answers given by different age groups.

In the case of medicinal water group, $74 \%$ of the participants were previously treated with Harkány medicinal water, while in the case of the tap water group 79\%. According to the statistical analysis, being familiar with the Harkány medicinal water did not influence the rate of correct answers (Table VI). 


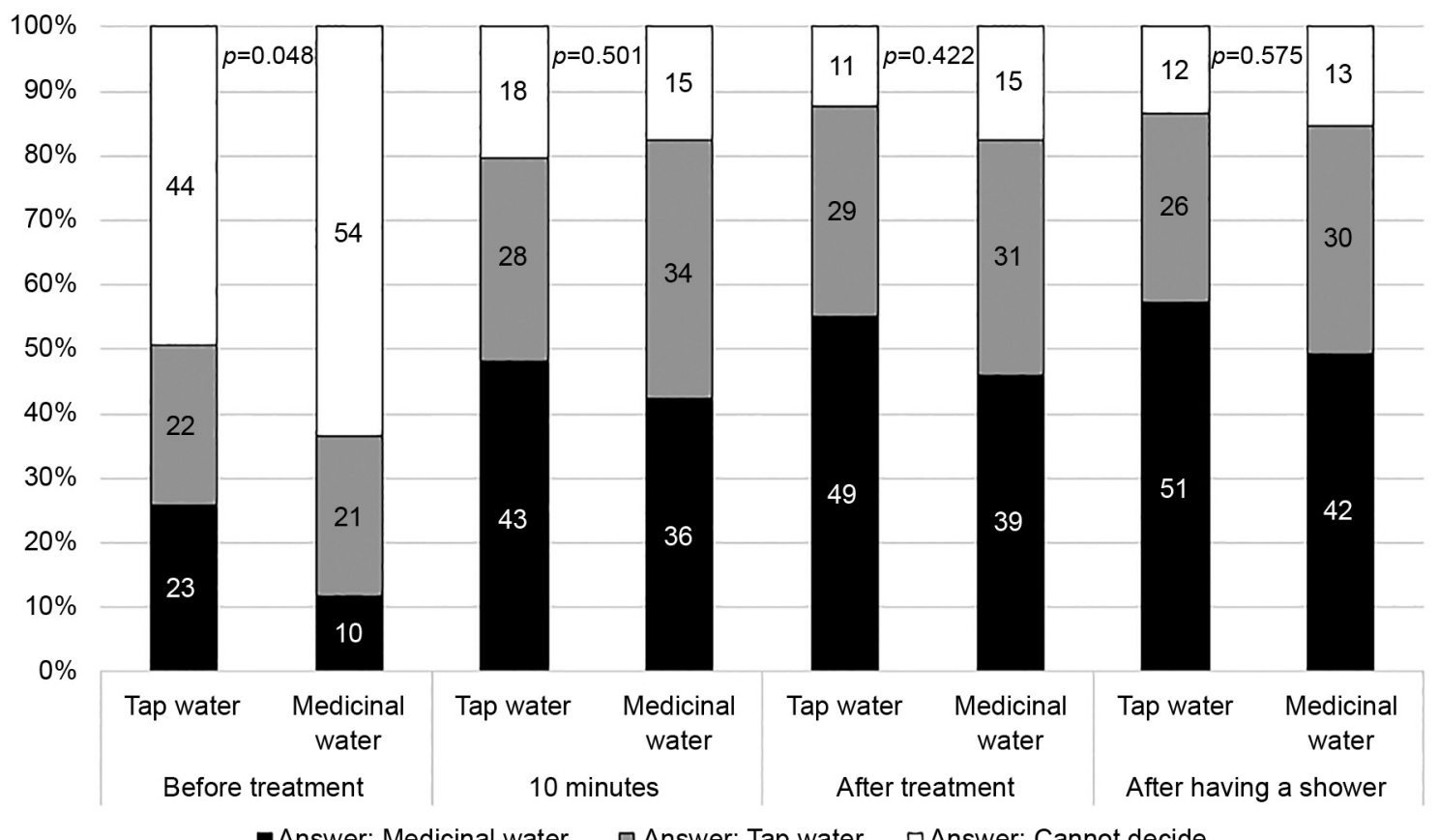

Figure 2. Summary of answers of the two groups.

Table V. Scores of the two groups.

\begin{tabular}{lccc}
\hline & $\begin{array}{c}\text { Medicinal water, } \\
\mathrm{n}(\%)\end{array}$ & $\begin{array}{c}\text { Tap water, } \\
\mathrm{n}=85\end{array}$ & $p$-Value \\
& $\mathrm{n}=89$ & \\
\hline 0 score & $33(38)$ & $45(51)$ & \\
1 score & $11(13)$ & $13(15)$ & \\
2 score & $11(13)$ & $9(10)$ & \\
3 score & $26(30)$ & $14(16)$ & \\
4 score & $4(5)$ & $8(9)$ & \\
Overall average score & $1.49 \pm 1.39$ & $1.18 \pm 1.43$ & 0.128 \\
\hline
\end{tabular}

As a factor of uncertainty, the number of changes of opinions was assessed. In the case of the tap water group, $31.5 \%(n=28)$ of the participants did not change the answer during the questioning, $52.8 \%(n=47)$ changed the answer once, $12.4 \%(n=11)$ twice, and $3.4 \%(n=3)$ three times. In the case of the medicinal water group, $20 \%(n=17)$ of the patients did not change their opinion, $61.2 \%$ changed $(n=52)$ once, $10.6 \%(n=9)$ twice, and $8.2 \%(n=7)$ three times. Comparing the results of the two groups, there was no statistically significant difference $(p=0.199)$ in the number of changes of opinions (Figure 3).
Table VI. Scores of the two groups previously treated with Harkány medicinal water.

\begin{tabular}{lccc}
\hline & $\begin{array}{c}\text { Medicinal water, } \\
\mathrm{n}(\%) \\
\mathrm{n}=63\end{array}$ & $\begin{array}{c}\text { Tap water, } \\
\mathrm{n}(\%) \\
\mathrm{n}=70\end{array}$ & $p$-Value \\
\hline 0 score & $27(42.9)$ & $35(50.0)$ & \\
1 score & $6(9.5)$ & $10(14.3)$ & \\
2 score & $10(15.9)$ & $8(11.4)$ & \\
3 score & $18(28.6)$ & $9(12.9)$ & \\
4 score & $2(3.2)$ & $8(11.4)$ & \\
Overall average score & $1.40 \pm 1.37$ & $1.21 \pm 1.46$ & 0.431 \\
\hline
\end{tabular}

\section{Discussion}

The effectiveness of medicinal waters in rehabilitation and treatment of several diseases has been described by numerous papers $(3,12,13,17,19,21,22)$. However, in some countries balneotherapy and medicinal water is not recognized as a financially supportable treatment method (24). One reason for this is the lack of properly performed placebo controlled RCTs in balneology research.

Most of the balneotherapeutic studies abroad have never used a placebo control $(15,16,25-37)$, despite the fact that 


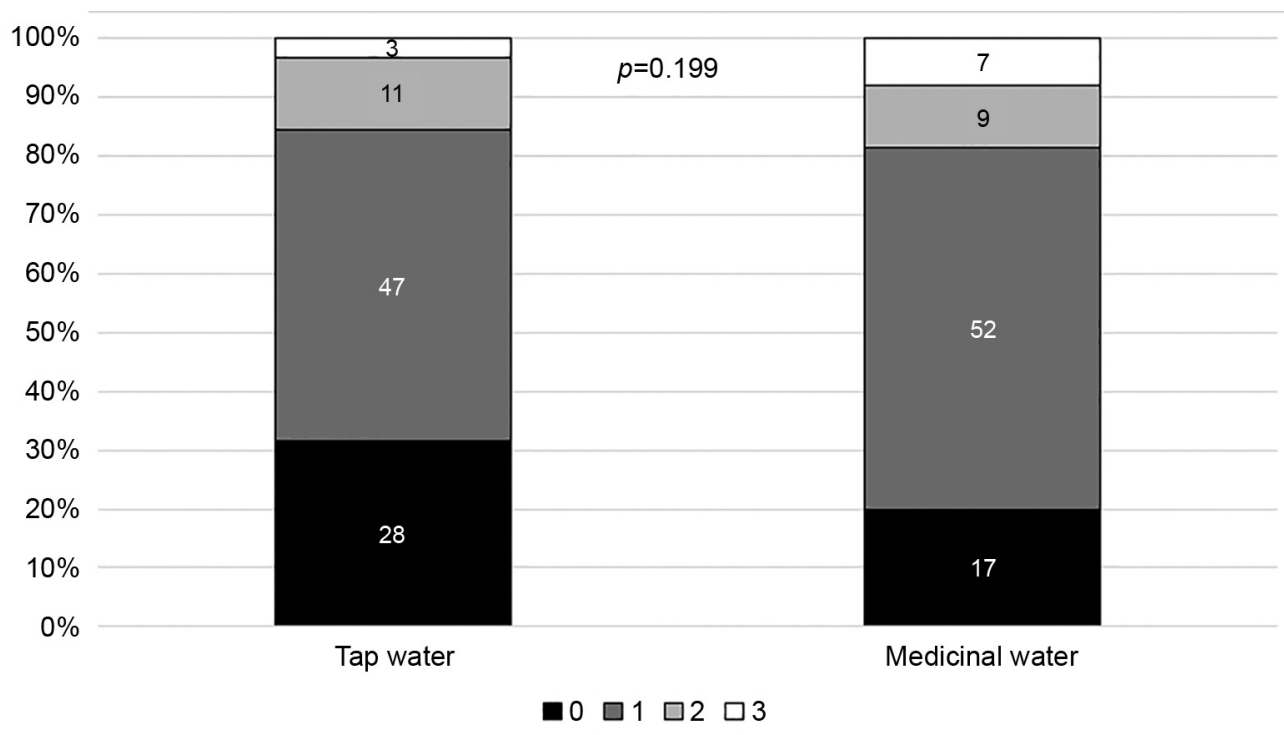

Figure 3. Number of changes of opinions.

this would be one of the most important steps in proving the beneficial effects of medicinal waters. In Hungarian studies, it is more common to use a placebo control $(4,7,38-40)$. In the field of balneotherapy, it is necessary to use only waterbased placebo controls. It should be noted how difficult it is to mimic the characteristics of medicinal waters (scent, colour, sensation, environment etc.) with tap water.

Even though the aforementioned studies used placebo controls, the fact whether the patients could actually distinguish between medicinal water and tap water was never examined. To resolve this issue, a preconception study should be performed to validate the placebo.

To the best of our knowledge, this is the first paper reporting a validated placebo development method for medicinal water-based rehabilitation research. Our goal was to assess whether the participants could detect that they were treated with medicinal water or tap water.

Regarding the average scores of the two groups no significant difference was found $(p=0.128)$.

Differences in answers $(p=0.048)$ were only found in the case of the first question (before treatment), where patients had to choose from the following answers: tap water, medicinal water or cannot decide - just by inspection. From the tap water group, twice as many patients answered that they were treated with medicinal water, which might be the reason for the differences mentioned above. Apart from the answers given to the first question (before treatment), in the following three questions, no differences were found in the right answers given by the two groups.

Most of the participants were previously treated with Harkány medicinal water. Interestingly, this did not influence the results of this study. In other words, being familiar with the medicinal water did not result in higher rate of identifying the medicinal water or tap water.

In the case of the tap water group nearly $70 \%$, and in the case of the medicinal water group $80 \%$ of the participants changed their answer at least once. This is another proof that the patients were quite uncertain whether they were treated with medicinal water or tap water.

Based on our findings, our opinion is that a placebo validation should be the first step before performing a randomized, controlled, double-blind clinical trial in balneotherapy research. The limitation of this trial is that this method is appropriate to produce placebo water only for Harkány medicinal water.

\section{Conflicts of Interest}

The Authors have no conflicts of interest to declare in relation to this study.

\section{Authors' Contributions}

Conceptualization: Balázs Németh, Katalin Szendi, Adrienn Hanzel, Iván Péter; Formal analysis and investigation: Károly Berényi; Methodology: Balázs Németh, András Sümegi, Katalin Szendi; Investigation: Balázs Németh, Katalin Szendi; Resources: Iván Péter, Csilla Hetesi, Zénó Ajtay; Participant enrolment: Csilla Hetesi; Statistics: Károly Berényi, Balázs Németh; Visualization: Balázs Németh, Katalin Szendi; Writing original draft: Balázs Németh. Katalin Szendi, Zénó Ajtay; Writing, review and editing: Ágnes Szenczi, Balázs Németh, Katalin Szendi. 


\section{Acknowledgements}

The Authors would like to thank the director and staff of the Harkány Spa Hospital for supporting this work. Chemical composition data of the Harkány tap water was kindly provided by Baranya Víz Zrt. This work was financially supported by the University of Pécs Medical School (ÁOK-KA-2019-07) and the National Research, Development and Innovation Office - NKFIH (FK_19. ID: FK 131531). The funder had no role in the study design, data collection and analysis, decision to publish, or preparation of the manuscript.

\section{References}

1 Routh HB, Bhowmik KR, Parish LC and Witkowski JA: Balneology, mineral water, and spas in historical perspective. Clin Dermatol 14(6): 551-554, 1996. PMID: 8960791. DOI: 10.1016/s0738-081x(96)00083-1

2 van Tubergen A and van der Linden S: A brief history of spa therapy. Ann Rheum Dis 61(3): 273-275, 2002. PMID: 11830439. DOI: $10.1136 /$ ard.61.3.273

3 Karagülle M and Karagülle MZ: Effectiveness of balneotherapy and spa therapy for the treatment of chronic low back pain: a review on latest evidence. Clin Rheumatol 34(2): 207-214, 2015. PMID: 25535198. DOI: 10.1007/s10067-014-2845-2

4 Kovács C, Pecze M, Tihanyi Á, Kovács L, Balogh S and Bender $\mathrm{T}$ : The effect of sulphurous water in patients with osteoarthritis of hand. Double-blind, randomized, controlled follow-up study. Clin Rheumatol 31(10): 1437-1442, 2012. PMID: 22843170. DOI: $10.1007 / \mathrm{s} 10067-012-2026-0$

5 Harkányfürdő. Available at: https://harkanyfurdo.hu/gyogyfurdo/ gyogyviz [Last accessed on May 3, 2021]

6 Varga C: Problems with classification of spa waters used in balneology. Health 02(11): 1260-1263, 2017. DOI: 10.4236/ health.2010.211187

7 Hanzel A, Berényi K, Horváth K, Szendi K, Németh B and Varga C: Evidence for the therapeutic effect of the organic content in Szigetvár thermal water on osteoarthritis: a doubleblind, randomized, controlled clinical trial. Int J Biometeorol 63(4): 449-458, 2019. PMID: 30734126. DOI: $10.1007 / \mathrm{s} 00484$ 019-01676-3

8 Szabó I and Varga C: Finding possible pharmacological effects of identified organic compounds in medicinal waters (BTEX and phenolic compounds). Int J Biometeorol 64(6): 989-995, 2020. PMID: 31673767. DOI: 10.1007/s00484-019-01808-9

9 Varga C, László M, Gerencsér G, Gyöngyi Z and Szendi K: Natural UV-protective organic matter in thermal water. J Photochem Photobiol B 144: 8-10, 2015. PMID: 25662041. DOI: 10.1016/j.jphotobiol.2015.01.007

10 Gerencsér G, Szabó I, Szendi K, Hanzel A, Raposa B, Gyöngyi $\mathrm{Z}$ and Varga $\mathrm{C}$ : Effects of medicinal waters on the UV-sensitivity of human keratinocytes - a comparative pilot study. Int $\mathrm{J}$ Biometeorol 63(10): 1417-1423, 2019. PMID: 31372755. DOI: 10.1007/s00484-019-01759-1

11 Varga C: Volatile organics in thermal spa waters: Active ingredients or environmental toxicants? Thermae Spa Med 1(1): 1-8, 2012.

12 Kesiktas N, Karakas S, Gun K, Gun N, Murat S and Uludag M: Balneotherapy for chronic low back pain: a randomized, controlled study. Rheumatol Int 32(10): 3193-3199, 2012. PMID: 21960048. DOI: 10.1007/s00296-011-2163-9
13 Bender T, Bálint G, Prohászka Z, Géher P and Tefner IK: Evidence-based hydro- and balneotherapy in Hungary - a systematic review and meta-analysis. Int J Biometeorol 58(3): 311-323, 2014. PMID: 23677421. DOI: 10.1007/s00484-0130667-6

14 Gupta U and Verma M: Placebo in clinical trials. Perspect Clin Res 4(1): 49-52, 2013. PMID: 23533982. DOI: 10.4103/22293485.106383

15 Buskila D, Abu-Shakra M, Neumann L, Odes L, Shneider E, Flusser D and Sukenik S: Balneotherapy for fibromyalgia at the Dead Sea. Rheumatol Int 20(3): 105-108, 2001. PMID: 11354556. DOI: $10.1007 / \mathrm{s} 002960000085$

16 Neumann L, Sukenik S, Bolotin A, Abu-Shakra M, Amir M, Flusser D and Buskila D: The effect of balneotherapy at the Dead Sea on the quality of life of patients with fibromyalgia syndrome. Clin Rheumatol 20(1): 15-19, 2001. PMID: 11254234. DOI: $10.1007 / \mathrm{s} 100670170097$

17 Szucs L, Ratko I, Lesko T, Szoor I, Genti G and Balint G: Double-blind trial on the effectiveness of the Puspokladany thermal water on arthrosis of the knee-joints. J R Soc Health 109(1): 7-9, 1989. PMID: 2494341. DOI: 10.1177/ 146642408910900104

18 Püspökladányi Strand- és Gyógyfürdő. Available at: http://termalfurdok.com/puspokladanyi-strand-es-gyogyfurdo/ [Last accessed on May 3, 2021]

19 Bálint GP, Buchanan WW, Adám A, Ratkó I, Poór L, Bálint PV, Somos E, Tefner I and Bender T: The effect of the thermal mineral water of Nagybaracska on patients with knee joint osteoarthritis - a double blind study. Clin Rheumatol 26(6): 890894, 2007. PMID: 17089219. DOI: 10.1007/s10067-006-0420-1

20 Termál Online. Available at: https://termalonline.hu/termalhirek/vegyen-gyogyfurdot-nagybaracska. [Last accessed on May 3, 2021]

21 Kovács I and Bender T: The therapeutic effects of Cserkeszölö thermal water in osteoarthritis of the knee: a double blind, controlled, follow-up study. Rheumatol Int 21(6): 218-221, 2002. PMID: 12036207. DOI: 10.1007/s00296-001-0167-6

22 Forestier R and Francon A: Components of crenobalneotherapy for knee osteoarthritis: A systematic review. In: Nonpharmacological therapies in the management of osteoarthritis. Henrotin Y, Bennell K, Rannou F (eds). Bentham e Books, pp. 64-80, 2012.

23 ClinCalc.com. Sample Size Calculator. Available at: https://clincalc.com/stats/samplesize.aspx [Last accessed on May $3,2021]$

24 Gutenbrunner C: Balneology and physical and rehabilitation medicine - differences, similarities and synergies. Annals of Physical and Rehabilitation Medicine 57: e159, 2018. DOI: 10.1016/j.rehab.2014.03.574

25 Vaht M, Birkenfeldt R and Ubner M: An evaluation of the effect of differing lengths of spa therapy upon patients with osteoarthritis (OA). Complement Ther Clin Pract 14(1): 60-64, 2008. PMID: 18243944. DOI: 10.1016/j.ctcp.2007.09.005

26 Dubois O, Salamon R, Germain C, Poirier MF, Vaugeois C, Banwarth B, Mouaffak F, Galinowski A and Olié JP: Balneotherapy versus paroxetine in the treatment of generalized anxiety disorder. Complement Ther Med 18(1): 1-7, 2010. PMID: 20178872. DOI: 10.1016/j.ctim.2009.11.003

27 Yurtkuran M, Ay A and Karakoç Y: Improvement of the clinical outcome in Ankylosing spondylitis by balneotherapy. Joint Bone 
Spine 72(4): 303-308, 2005. PMID: 16038841. DOI: 10.1016/ j.jbspin.2004.06.006

28 Karagülle M, Kardeş S, Dişçi R and Karagülle MZ: Spa therapy adjunct to pharmacotherapy is beneficial in rheumatoid arthritis: a crossover randomized controlled trial. Int J Biometeorol 62(2): 195-205, 2018. PMID: 28884308. DOI: 10.1007/s00484-017$1441-y$

29 Karagülle M, Kardeş S and Karagülle MZ: Long-term efficacy of spa therapy in patients with rheumatoid arthritis. Rheumatol Int 38(3): 353-362, 2018. PMID: 29327104. DOI: 10.1007/ s00296-017-3926-8

30 Fioravanti A, Bacaro G, Giannitti C, Tenti S, Cheleschi S, Gui Delli GM, Pascarelli NA and Galeazzi M: One-year follow-up of mud-bath therapy in patients with bilateral knee osteoarthritis: a randomized, single-blind controlled trial. Int J Biometeorol 59(9): 1333-1343, 2015. PMID: 25516113. DOI: 10.1007/ s00484-014-0943-0

31 Fioravanti A, Tenti S, Giannitti C, Fortunati NA and Galeazzi M: Short- and long-term effects of mud-bath treatment on hand osteoarthritis: a randomized clinical trial. Int J Biometeorol 58(1): 79-86, 2014. PMID: 23314489. DOI: 10.1007/s00484012-0627-6

32 Forestier R, Desfour H, Tessier JM, Françon A, Foote AM, Genty C, Rolland C, Roques CF and Bosson JL: Spa therapy in the treatment of knee osteoarthritis: a large randomised multicentre trial. Ann Rheum Dis 69(4): 660-665, 2010. PMID: 19734131. DOI: 10.1136/ard.2009.113209

33 Dönmez A, Karagülle MZ, Tercan N, Dinler M, Işsever H, Karagülle $M$ and Turan M: SPA therapy in fibromyalgia: a randomised controlled clinic study. Rheumatol Int 26(2): 168172, 2005. PMID: 15965635. DOI: 10.1007/s00296-005-0623-9

34 Evcik D, Kizilay B and Gökçen E: The effects of balneotherapy on fibromyalgia patients. Rheumatol Int 22(2): 56-59, 2002. PMID: 12070676. DOI: 10.1007/s00296-002-0189-8

35 Yurtkuran M and Celiktas M: A randomized, controlled trial of balneotherapy in the treatment of patients with primary fibromyalgia syndrome. Physikalische Medizin, Rehabilitationsmedizin, Kurortmedizin 06(04): 109-112, 2017. DOI: 10.1055/s-20081061917
36 Karagülle M, Karagülle MZ, Karagülle O, Dönmez A and Turan M: A 10-day course of SPA therapy is beneficial for people with severe knee osteoarthritis. A 24-week randomised, controlled pilot study. Clin Rheumatol 26(12): 2063-2071, 2007. PMID: 17431728. DOI: $10.1007 / \mathrm{s} 10067-007-0618-\mathrm{x}$

37 Ekmekcioglu C, Strauss-Blasche G, Holzer F and Marktl W: Effect of sulfur baths on antioxidative defense systems, peroxide concentrations and lipid levels in patients with degenerative osteoarthritis. Forsch Komplementarmed Klass Naturheilkd 9(4): 216-220, 2002. PMID: 12232493. DOI: 10.1159/000066031

38 Hanzel A, Horvát K, Molics B, Berényi K, Németh B, Szendi K and Varga C: Clinical improvement of patients with osteoarthritis using thermal mineral water at Szigetvár Spa-results of a randomised double-blind controlled study. Int J Biometeorol 62(2): 253-259, 2018. PMID: 28956169. DOI: 10.1007/s00484017-1446-6

39 Balogh Z, Ordögh J, Gász A, Német L and Bender T: Effectiveness of balneotherapy in chronic low back pain - a randomized single-blind controlled follow-up study. Forsch Komplementarmed Klass Naturheilkd 12(4): 196-201, 2005. PMID: 16137981. DOI: 10.1159/000086305

40 Zámbó L, Dékány $\mathrm{M}$ and Bender T: The efficacy of alumcontaining ferrous thermal water in the management of chronic inflammatory gynaecological disorders-a randomized controlled study. Eur J Obstet Gynecol Reprod Biol 140(2): 252257, 2008. PMID: 18511175. DOI: 10.1016/j.ejogrb.2008.03.015
Received June 4, 2021

Revised June 16, 2021

Accepted June 17, 2021 